\title{
ТЕХНІЧНI НАУКИ
}

DOI: https://doi.org/10.32839/2304-5809/2021-8-96-1

УДК 001:004.91

Березінський Г.В.

Національний технічний університет України «Київський політехнічний інститут імені Ігоря Сікорського»

\section{АНАЛІЗ ПУБЛІКАЦІЙ ВИКЛАДАЧІВ ЗАКЛАДУ ВИЩОЇ ОСВІТИ НА ОСНОВІ ВІДКРИТИХ ДАНИХ}

\begin{abstract}
Анотація. В даній роботі розглянуто методики використання наукометричних даних для дослідження наукової діяльності викладачів закладу вищої освіти на основі інформації, взятої з відкритих бібліограdpiчних та pedpepативних баз даних Google Scholar та Scopus, дослідження профілів викладачів та виявлення публікацій, що були асоційовані з викладачем помилково. Пропонуеться огляд існуючих алгоритмів визначення помилково доданих публікацій в профіль Google Scholar. Представлений аналіз існуючих досліджень, їх переваг та недоліків у рамках поставленої задачі, виділена проблематика, не розкрита у попередніх публікаціях. Наведений алгоритм з визначення помилкових публікацій, заснований на пошуку автора та співавтора. Описано недоліки такого підходу та плани на подальше дослідження для зменшення кількості помилкових результатів та пришвидшення часу роботи аналізатора.
\end{abstract}

Ключові слова: рейтинг, наукометрія, Scopus, Google Scholar, h-індекс, індекс Хірша, публікація, помилкова публікація.

Berezinskyi Hennadii National Technical University of Ukraine «Igor Sikorsky Kyiv Polytechnic Institute»

\section{ANALYSIS OF PUBLICATIONS OF TEACHERS OF HIGHER EDUCATIONAL INSTITUTIONS ON THE BASIS OF SCIENTIFIC METRIC DATA}

Summary. This work is devoted to the analysis of publications of scientists taken from open bibliographic and scientometric databases Google Scholar and Scopus. Particular attention will be paid to the Google Scholar service, which, although less influential, since it takes into account all publications and membership are free, it has a wider base of scientific work. This paper discusses methods of using scientometric data to study the scientific activities of teachers of higher education based on information taken from open bibliographic and abstract databases Google Scholar and Scopus, research profiles of teachers, and identify publications that were associated with the teacher by mistake. An overview of existing algorithms for identifying erroneously added publications to your Google Scholar profile is offered. The analysis of the existing researches, their advantages and lacks within the limits of the set task is presented, the problems which are not opened in the previous publications are allocated. An algorithm for determining erroneous publications based on the search for the author and co-author is presented. The disadvantages of this approach are described and plans for further research to reduce the number of false positives and speed up the analyzer. The described algorithm works on comparison of the name of the scientist taken from a profile with authors of publications checking a surname and initials with co-authors as one criterion. This paper also examines publications that describe the general provisions of scientometrics, such as science, the formation and use of the Hirsch index to assess the journalistic activity of the teacher, the shortcomings of this method and offers alternatives and a publication that offers an algorithm for confirming authorship based on co-authorship graphs. The disadvantages of this approach are presented, the unresolved issues in the context of the problem are highlighted and the method of their solution by the above-mentioned algorithm is proposed. Ways of further research and options for improving the algorithm to reduce operating time and increase accuracy are presented. This publication also reviews the methods of evaluating the scientific activity of the Higher Educational Institution's teachers and describes the formation of the Hirsch index for one scientist and scientific departments of the university.

Keywords: rating, science, scopus, google scholar, h-index, hirch index, publication, wrong publication.

$\Pi^{2}$ остановка проблеми. Дана робота присвячена аналізу публікацій науковців, взятих з відкритих бібліографрічних та наукометричних баз даних Google Scholar та Scopus. Ocoбливий акцент буде зроблено на сервісі Google Scholar. Незважаючи на менший рівень впливу, він враховує ширше коло видань та містить більшу базу наукових робіт.

Cepвic Google Scholar має особливість - в налаштуваннях можливо встановити дозвіл на автоматичне додавання публікацій у профріль науковця. Виконуючи пошук по кожному науковцю у від- критих джерелах, Google Scholar автоматично додає у свою базу ті публікації, автором яких вважає даного науковця. У більшості випадків, такі публікації додаються коректно. Проте іноді до профілю викладача публікація додаеться помилково.

Наявність помилково доданих публікащій в профрілях викладачів, при підрахунку міжнародних рейтингів закладів вищої освіти (Webometrics, UniRank, Times Higher Education, QS, U-Multirank, ARWU та ін.), карається штрафрними санкціями: штрафні рейтингові бали, або вилучення навчального закладу з рейтингу, при великій кількості 
порушень. Тому своєчасне визначення помилково доданих публікацій є важливим.

У цій роботі пропонуються рішення аналізу наукометричних даних науковців на предмет помилково доданих публікацій. Можливості досліджуваних методів будуть продемонстровані на прикладі науковців НТУУ «КПІ ім. Ігоря Сікорського». Усі використані дані взято з відкритих джерел.

Аналіз останніх досліджень та публікацій. Оцінювання наукової діяльності викладача закладу вищої освіти (ЗВО) є однією з основних складових рейтингів, що визначають науковий вклад та престижність навчальних закладів.

Через це важливо вірно відслідковувати наукову активність співробітників ЗВО.

При складанні рейтингів, для оцінки наукової діяльності, використовують так званий h-індекс, або індекс Хірша. Індекс Хірша використовується такими системами, як Google Scholar, Scopus, Web of Science та інші.

Для вимірювання едективності наукової діяльності викладачів використовуються різні наукометричні показники. Найбільш розповсюдженими показниками є:

- цитування, що визначається як сума бібліографрічних посилань;

- загальна кількість статей;

- індекс Хірша, що визначається як максимальне значення $\mathrm{h}$, таке що даний автор опублікував h статей, кожна з яких була процитована не менше h раз;

- i10 індекс, що показуе кількість публікащій, що мають принаймні 10 бібліографічних посилань;

- деякі інші різновиди індексу Хірша, як g-індекс.

Загальна кількість статей не враховує якість наукових публікацій, в той час, як на загальну кількість цитувань може непропорційно вплинути участь однієї публікації, що має істотний вплив (наприклад, методологічні статті, що пропонують успішні нові технології, або методичні матеріали, які можуть генерувати велику кількість цитат), або багато публікацій з малою кількістю цитат.

В зазначених вище базах використовується метрики h-індексу (індексу Хірша).

Спільними рисами для наукових публікащій на дану тематику є відсутність описаного методу збору даних, аналізу наукових профрілів викладачів, описаних методів подальшого використання отриманої інформації.

Стаття «Алгоритм вирішення неоднозначності імен авторів» [1] пропонуе вирішення задачі неоднозначного авторства публікацій у деяких наукометричних системах. Автор статті пропонує використовувати наведений нижче алгоритм для точної ідентифрікації авторства статті.

На першому кроці виділяються елементи бібліографрічного опису: імена науковців, назви публікащій, тощо. Далі відбуваеться пошук на предмет можливих дублікатів у системі - це дає можливість точної ідентифрікації всередині системи. 3 бібліографрічних описів виділяеться ПІБ окремих авторів та будуеться графр співавторства. По текстовому опису відбувається пошук IRID авторів, та за допомогою графру співавторства, виділяються найбільш імовірні пари авторів, що видаються користувачу у якості результату.
Дослідження алгоритму демонструє високу точність визначення некоректно доданих публікащій, а саме $97 \%$.

Дана стаття не порушуе питання збору наукометричних даних. Також допускає недоліки при визначені співавторства, а саме - алгоритм будуе графр співавторства, в якому вказуе всі важливі варіанти можливого співавторства та оцінюеться ймовірність правильності такого набору. Це дає високу точність визначення, проте збільшуе алгоритмічну складність. Алгоритм не використовує дані про авторизацію користувачів у системі, проте вони містять значну кількість інформації про авторство робіт.

Наукова робота "Relevance of innovations in machine learning to scientometrics» [2] описує теоретичні методи використання технології глибокого навчання у наукометрії для аналізу та обробки даних. Автор дослідження просуває ідею використання наступних технологій:

- моделей автоматичного визначення критеріїв;

- методів статистичного аналізу з використанням алгоритмів глибокого навчання;

- використання класифікації і кластеризації даних для їх аналізу.

Проте у роботі не наведено реальних досліджень, конкретних алгоритмів, або результатів використання даних методів.

Виділення невирішених раніше частин загальної проблеми. У наведених вище публікащіях не розглядаються методи подальшого статистичного аналізу даних про наукову діяльність викладацького складу закладу вищої освіти, а також методи й моделі автоматизованого збору даних з відкритих джерел (Google scholar, Scopus, Web of Science та інші).

Представлені в дослідженнях методи аналізують правильність визначення авторства публікацій на основі інших публікацій, тобто не здатні проаналізувати окремі публікації. Відповідно, точність роботи методів зменшуеться із зменшенням кількості публікацій у окремого науковця. В той же час, робота [2] не пропонуе практичних методів вирішення проблеми правильності визначення авторства публікащії.

Постановка завдання. Метою даного дослідження є пошук методів та алгоритмів для мінімізації впливу недоліків системи автоматичного додавання публікацій до наукометричних баз даних на збір та аналіз інформації про наукову діяльність викладачів ЗВО. Це досягається шляхом покращення методів визначення авторства публікації, та вдосконаленням методів комплексного збору та аналізу даних про наукову та публіцистичну діяльність.

У cepвici Google Scholar відсутне нормування, що задає єдині вимоги до заповнення проділю користувачів-науковців. У зв'язку 3 цим, для кожного викладача необхідно індивідуально визначити критерії для порівняння метаданих публікації на основі загальних критеріїв, за якими можна було б ідентифрікувати публікацію, як потенційно помилкову.

Аналіз на підтвердження авторства публікацій. Однією 3 проблем підтвердження авторства $є$ необхідність обробки великих масивів даних. Для близько 2700 викладачів НТТУ «КПІ ім. Ігоря Сікорського» було зібрано більше 
70 тисяч публікащій, базуючись на даних, взятих 3 cepвicy Google Scholar. Тому при створенні алгоритму аналізу необхідно враховувати час роботи алгоритму, умови обмеженості ресурсів, кількість помилкових результатів. Помилковий результат - типовий наслідок задач, які можуть бути зведені до задачі класифікації, як задача підтвердження авторства (авторство публікації або підтверджується або ні).

Процес підтвердження авторства публікації складається 3 декількох етапів.

Підготовчий етап - збір необхідних даних: ПІБ викладача та його публікації у системі Google Scholar. Наявність в продрілі викладача імені та прізвища, продубльованих кирилицею та латиницею, допоможе зменшити ймовірність помилкового результату. Для кожної публікації збираються дані про їі авторів, назву, рік, видавництво та кількість цитувань.

На наступних етапах йде перевірка кожної публікації автора. Для кожної публікації необхідно перевірити наявність імені та прізвища науковця у списку авторів. Враховуючи, що прізвище автора береться з його профілю, можливе хибне спрацьовування за умови відсутності імені, імені по-батькові, а також при використанні ініціалів без повного імені тощо. Через це необхідно привести імена до одного фрормату.

Для цього система перевіряе наявність у імені науковця символів кирилиці та латинці. При позитивному результаті можна стверджувати, що ім'я продубльовано на іноземній мові. У випадку відсутності таких символів, система двічі транслітерує ім'я викладача та додає транслітеровані імена до зчитаних 3 профілю. Подвійна транслітерація необхідна для врахування різних способів транслювання одного символу (пр. українська літера «i» можу бути транслітерована на «і» або «у»).

Наступний етап - виділення ініціалів 3 повного імені шляхом обрання перших літер слів повного імені.

Після отримання підготовчих даних система може провести аналіз публікації. Використовуються ознаки (критеріï):

1. Серед прізвищ авторів наукової роботи немає точного співпадіння з прізвищем власника профілю, у якому вона зазначена.

2. Ініціали науковця, зазначені у авторах публікації, не відповідають дійсності.

3. Серед співавторів публікації немає жодного співробітника того ж самого закладу вищої освіти.

На рисунку 1 представлене схематичне зображення описаного алгоритму.

Для зменшення ймовірності отримання помилкових результатів, вважатимемо, що достатніми умовами для визначення публікації, як доданої помилково, є виконання лише першої, або другої та третьої ознак одночасно. Друга та третя ознаки не $є$ достатніми окремо через те, що деякі імена мають різний правопис у різних мовах, що використовують кирилицю (пр. «Александр» російською та «Олександр» на українській мові). Це дозволяе зменшити кількість помилково-позитивних результатів. Третя умова працюе лише комплексно 3 іншими умовами, оскільки не гарантуе ніякого результату взагалі.

Як приклад, наведемо типові помилкові публікації, що визначаються програмою.
Прикладом виконання першого критерію $\epsilon$ публікація, що була додана в профіль викладача Гавриленко О.В. На рисунку 2 представлена розширена інформація про дану публікацію.

На рисунку зрозуміло, що публікація була випадково додана в профіль, та не належить викладачу.

При перевірці профріля науковця Савицької O.М., була виявлена публікація, яка належить Савицькій О.С. На рисунку 3 представлено розширений опис даної публікації в профрілі Google Scholar Савицької O.M.

Одним 3 можливих критеріїв $є$ аналіз за джерелом публікації. Ідея полягає у тому, щоб виключати помилковий результат, якщо інші публікації цього автора у видавництві все були перевірені. Втім, такий критерій не є надійним через відсутність нормування або єдиної бази видавництв, які враховуються у Google Scholar. Це означає, що у назві публікацій можуть допускатись помилки. Це робить критерій ненадійним навіть у поєднанні з іншими критеріями.

Дана модель матиме широке застосування у розв'язку проблеми неоднозначності авторства публікацій. Перевага методу у тому, що помилкова публікація буде знайдена з високою ймовірністю. Але зазначений метод має певні недоліки. Основним недоліком представленого методу $€$ довга робота алгоритму та велика кількість помилково-позитивних результатів. Помилковопозитивним результатом вважаеться знайдена публікація, що відповідае критеріям визначення помилково доданих публікацій, проте не є такою.

До цього може призводити некоректне оформлення профрілю науковця у системі Google Scholar, a came:

- відсутність дубляжу імені на інших мовах;

- у профрілі не вказано ініціали.

Таким чином, для уникнення можливості потрапляння помилково доданої публікації у профіль користувача, та для полегшення виявлення таких публікацій, рекомендовано дотримуватися наступних правил:

- дублювати повне ім'я на усіх мовах, за необхідності транслітерацію україномовного та російськомовного написання;

- вказувати місце роботи у профілі у відповідності з тим, що вказуеться у публікаціях;

- додавати в профріль підтверджену електронну адресу у домені навчального закладу.

Наведемо узагальнені результати досліджень у таблиці 1.

Таблиця 1

Узагальнені результати аналізу публікацій

\begin{tabular}{|l|c|}
\hline Усього публікацій & 77079 \\
\hline $\begin{array}{l}\text { Унікальних публікацій } \\
\text { (з урахуванням співавторів) }\end{array}$ & 63456 \\
\hline Помічено, як ненадійні за 1-шою ознакою & 7934 \\
\hline $\begin{array}{l}\text { Помічено, як ненадійні } \\
\text { за 2-гою та 3-тьою ознаками }\end{array}$ & 18781 \\
\hline 3 них за трьома ознаками & 7893 \\
\hline
\end{tabular}

У подальших дослідження плануеться покращити алгоритм визначення потенційно помилкових публікацій. Для цього будуть проведені експерименти з різними комбінаціями ознак не- 


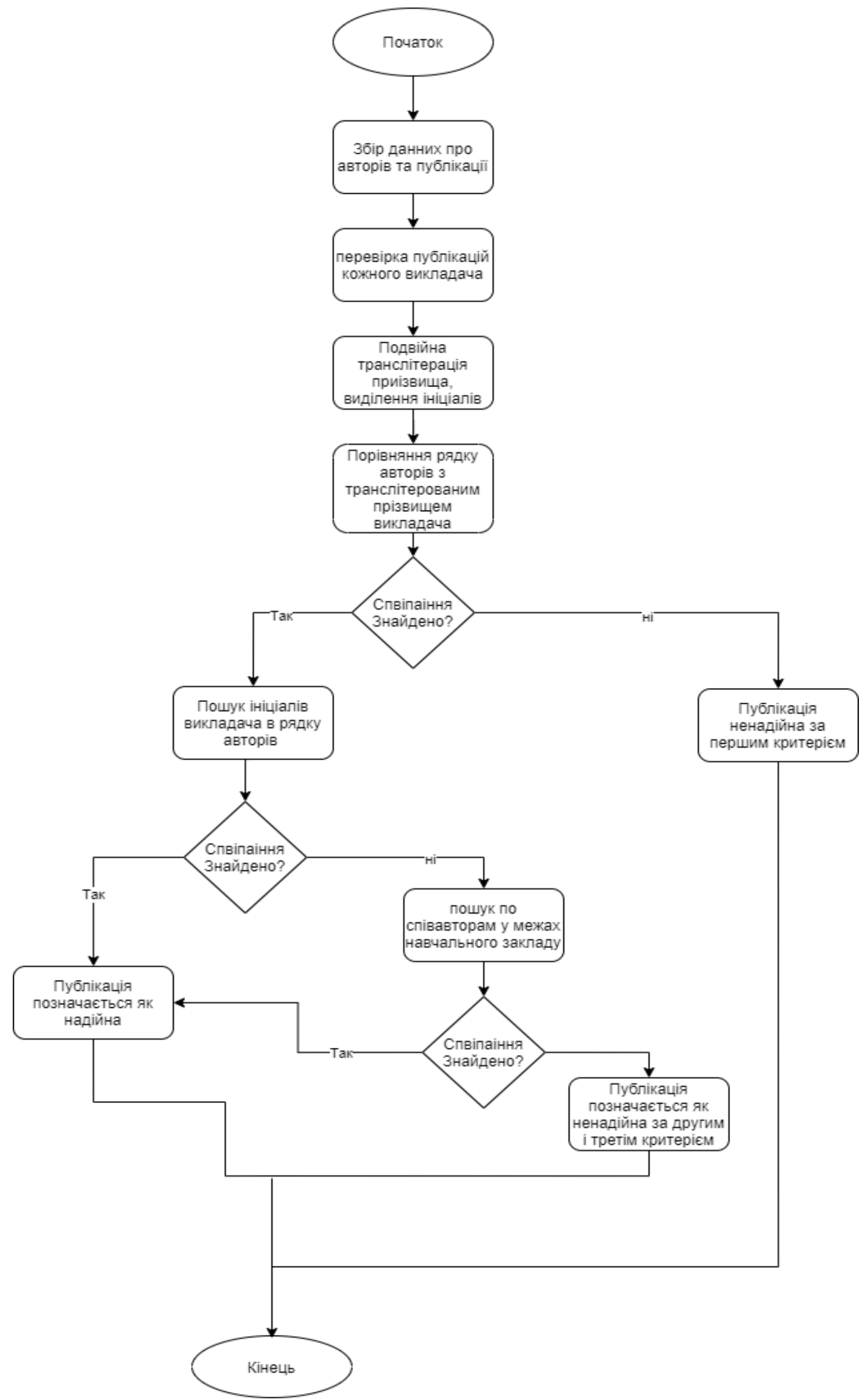

Рис. 1. Блок-схема алгоритму 
ЗАХИСТ ІНФОРМАЦІІІ, ТОМ 15, № 3, ЛИПЕНЬ-ВЕРЕСЕНЬ 2013

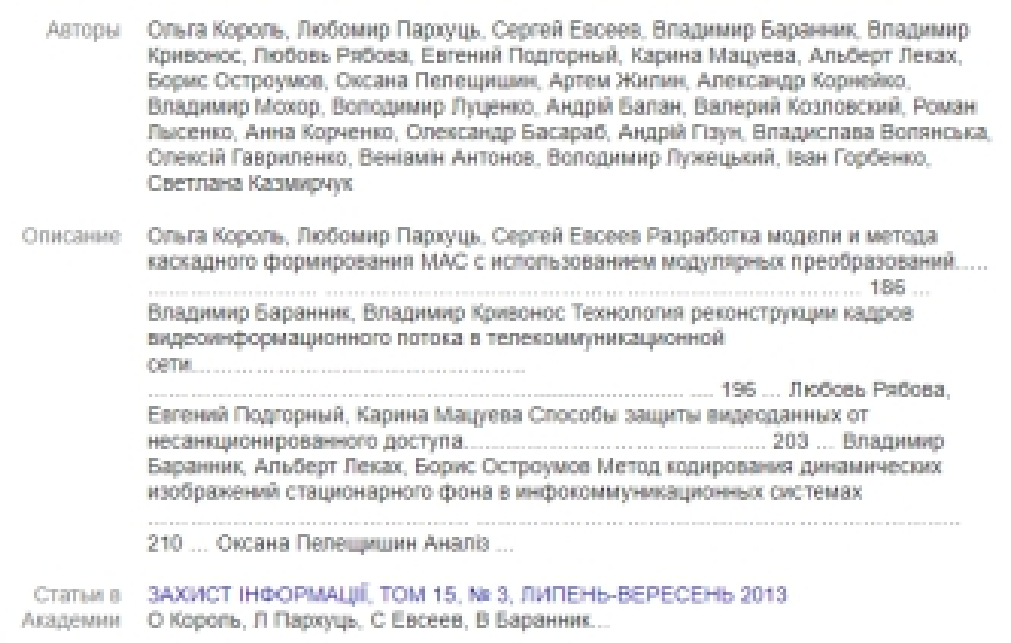

Рис. 2. Розширена інформація про публікацію

Розвиток обдарованості учнів на уроках трудового навчання в умовах допрофільної підготовки

Ос Савицька

Науковий часопис нПу імені МП Драгоманова. Серія 5: Педагогічні науки ...

Рис. 3. Розширена інформація про публікацію

надійності публікації та введення нових (наприклад, тематика публікації). Також планується провести дослідження у напрямку покращення методів наближеної транслітерації імен, використання методів обробки великих даних для зменшення часу аналізу публікацій та використання класифрікації і кластеризації для більш точного виявлення помилкових публікацій.

Залишається нерозв'язаною проблема повних однофрамільців (збіг повного імені та прізвища). Для невеликих навчальних закладів перевірка по співавторам має вирішувати цю проблему, але для більших університетів вона залишається актуальною.

Висновок. Наведені вище методи ощінки правильності визначення авторства публікації дозволяють автоматизувати ручний процес перевірки профрілів та публікацій науковців. Це полегшує процес спостереження за публіцистичною активністю викладачів закладу вищої освіти, та дозволяе краще розуміти процеси наукової діяльності у різних підрозділах у межах ЗВО. Представлений алгоритм дозволить уникати можливих проблемних ситуацій 3 неправильно визначеними публікаціями у сервісі Google Scholar.

Даний алгоритм не є досконалим через високу алгоритмічну складність та велику кількість помилково-позитивних результатів. Це пояснюеться наступними фракторами:

- відсутність нормування даних сервісом Google Scholar;

- відсутність у частини користувачів сервісу повного імені у профрілі;

- неправильне оформленням метаданих публікацій;

- відносна простота алгоритму.

Незважаючи на це, описані методи показують гарні результати у виявлені помилково доданих публікацій. Подальше вдосконалення та додавання нових алгоритмів визначення автора дозволить суттево знизити час роботи аналізатора та зменшити кількість помилкових результатів.

\section{Список літератури:}

1. Козицин А.С., Афонин С.А. Алгоритм разрешения неоднозначности имен авторов в ИАС ИСТИНА. Современные инфбормационные технологии и ИТ-образование. 2020. № 16.1.

2. Srinivasa G. Relevance of innovations in machine learning to scientometrics. Journal of Scientometric Research. 2019. № 8. C. 39-43.

3. Березінський Г. Інформаційна система визначення критеріїв технології підтримки науково-публіцистичної діяльності науковців закладу вищої освіти (комплексна тема). Загальна частина. Підсистеми автоматичного добування наукометричних даних науковців-викладачів ЗВО. Індивідуальна частина № 1. Бакалаврські Роботи (АСОIУ). 2020. 
4. Мамонтов В.В., Березінський Г.В., Аналіз наукометричних даних та складання рейтингу підрозділів КПІ ім. Ігоря Сікорського на основі публіцистичної діяльності викладачів : IV Всеукраїнська науково-практична конференція молодих вчених та студентів "Інфорлаційні систели та технології управління ІСТУ-2020». Секція кафбедри автолатизованих систел обробки інфборлацї і управління. Матеріали конфберенції. Київ, 2020. 24, 30 квітня 2020 р. С. 110-118.

\section{References:}

1. Kozicyn, A.S., \& Afonin, S.A. (2020) Algoritm razresheniya neodnoznachnosti imen avtorov v ias istina. Sovremennye informacionnye tekhnologii $i$ IT-obrazovanie, 16(1). DOI: https://doi.org/10.25559/SITITO. 16.202001.108-117

2. Srinivasa, G. (2019) Relevance of Innovations in Machine Learning to Scientometrics. Journal of Scientometric Research, 8(2s), pp. 39-43.

3. Berezins'kij, G.V. (2020) Informacijna sistema viznachennya kriteriïv tekhnologiï pidtrimki naukovopublicistichnoï diyal'nosti naukovciv zakladu vishchoï osviti (kompleksna tema). Zagal'na chastina. Pidsistemi avtomatichnogo dobuvannya naukometrichnikh danikh naukovciv-vikladachiv ZVO. Individual'na chastina № 1 (Bachelor's thesis, KPI im. Igorya Sikors'kogo).

4. Mamontov V.V., Berezinskyi H.V. (2020) Analiz naukometrychnykh danykh ta skladannia reitynhu pidrozdiliv KPI im. Ihoria Sikorskoho na osnovi publitsystychnoi diialnosti vykladachiv: IV Vseukrainska naukovopraktychna konferentsiia molodykh vchenykh ta studentiv «Informatsiini systemy ta tekhnolohii upravlinnia ISTU-2020». Sektsiia kafedry avtomatyzovanykh system obrobky informatsii i upravlinnia. Materialy konferentsii. Kyiv. 